Egyptian Journal of Aquatic Biology \& Fisheries

Zoology Department, Faculty of Science,

Ain Shams University, Cairo, Egypt.

ISSN $1110-6131$

Vol. 25(5): 253 - 270 (2021)

www.ejabf.journals.ekb.eg

\title{
Assessment of Ocimum basilicum Extracts on Schistosoma mansoni Infected Biomphalaria alexandrina Snails and Mice
}

\author{
Hanan S. Mossalem ${ }^{1}$, Gehan L. Abuelenain 2, *, Asmaa S. Mohamed ${ }^{3}$, \\ Tamer S. Mohamed ${ }^{3}$, Khaled M. Zayed ${ }^{1}$, Soheir S. Mahmoud ${ }^{2}$ \\ ${ }^{1}$ Medical Malacology Department, \\ ${ }^{2}$ Parasitology Department, \\ ${ }^{3}$ Medicinal Chemistry Department, Theodor Bilharz Research Institute, Giza, Egypt. \\ "Corresponding Author: : gehanlha@yahoo.com
}

ARTICLE INFO

Article History:

Received: July 28, 2021

Accepted: Aug. 29, 2021

Online: Sept. 27, 2021

Keywords:

Ocimum basilicum, antioxidants, anti-schistosomiasis, Biomphalria alexandrina
Schistosomiasis is one of the most prevalent diseases worldwide despite the conventional drug praziquantel and the molluscicides. The quest for a free-toxic clinical treatment and friendly-environmental and molluscicide has intensified. In this study, the compositions of African Ocimum basilicum plant extracts were prepared and analyzed. Then, their cytotoxicity, antioxidant, and antischistosomiasis impacts were studied. The constituents of $O$. basilicum essential oil and ethanol extract were analyzed by the HPLC and GS/MS techniques, respectively. DPPH and SRB assays were applied to test the antioxidant activity and cytotoxicity of the two extracts, respectively. Furthermore, the efficacy of both extracts on Schistosoma mansoni-infected B. alexandrina snails and mice was examined. The results demonstrated that the ethanol extract has fourteen compounds with different concentrations: Caffeic acid (553.46 mg) is the highest concentration, and carnosic acid $(79.14 \mathrm{mg})$ is the lowest. However, the essential oil analysis revealed more components $(n=25)$ with the highest content due to linalool (21.52\%), and the lowest is phytol acetate (8\%). Exposure of $B$. alexandrina snails to $O$. basilicum extracts $(50 \mathrm{ppm}$, each) showed a significant $(P<0.001)$ decrease in the infection rates $(35 \%$ and $21 \%$, respectively) and increase in the survival rates (95\% and $96 \%$, respectively) compared to the untreated, infected snails (85\% and 95, respectively). The administration of mice with the mono $O$. basilicum extracts significantly reduced the worm burden, egg loads, and intact eggs in favor of the essential oil. Interestingly, our study demonstrated more fibro-cellular hepatic granulomas in the mice treated with the ethanol extract than in mice treated with the essential oil. In conclusion, our data is suggesting a promising anthelminthic and antioxidant herb. Further investigations are to be considered to examine the effectiveness of O. basilicum extracts in combination with praziquantel.

\section{INTRODUCTION}

Schistosoma mansoni is a neglected parasitic disease caused by the genus Schistosoma, resulting in a global socioeconomic affliction (McManus et al., 2018). The WHO reported 250 million people infected with Schistosoma spp. and around 800 million people at risk of infection worldwide (WHO, 2020; Li et al., 2021). The 
life cycle of the parasite is complex and continuous between intermediate and definitive hosts. In freshwater, eggs hatch into miracidia that transform into cercariae in a specific snail host and depart from the snails to infect the definitive mammalian host (e.g., human) via skin. Through the host's bloodstream, the cercariae reach the intestinal mesentery, differentiate into male and female parasites that couple and mate to give rise to ova. Many intact eggs result in hepatic and intestinal pathological changes ending up with chronic granulomas, and the others depart the host through the feces (Olivier and Mao 1949; Cort et al., 1954; Whitfield and Evans, 1983, Pearce and MacDonald, 2002)

Since the early eighties, praziquantel (PZQ) has been the only reliable treatment of schistosomiasis. It is affordable, safe, and highly efficient in treating trematodes and cestodes in humans and animals. Yet, there is an emergence of resistance to the PZQ drug and molluscicides in some areas (Ismail et al., 1999; King et al., 2000; Utzinger et al., 2001; Jiwajinda et al., 2002; Doenhoff et al., 2008; Bergquist et al., 2017). These challenges urged the researchers to study the botanical products potential effects on schistosomiasis as reported by WHO (2019) and Duarte Galhardo de Albuquerque et al. (2020).

The medicinal herbs have been utilized since 1993 in the control of Schistosoma intermediate host for being cheap and ecofriendly (Archiblad, 1933; Wager, 1936; Mozley, 1939; Lemma et al., 1978; Hostettmann, 1984; Mølgaard et al., 2001; Mossalem et al., 2013; 2017; Simoben et al., 2018). Many in vitro studies were conducted on Schistosoma mansoni to test the effect of some African plants on the growth of the parasite stages. At the same time, only a few in vivo assessments were considered to evaluate the efficacy of those plants (Duarte Galhardo de Albuquerque et al., 2020). Many plants were screened for their efficacy against the adult worms (Yousif $\boldsymbol{e t}$ al., 2012), and only Ocimum Americanum extracts were tested for their anti-schistosomicidal activity in a murine model in Kenya (Waiganjo et al., 2014). The current study aimed to evaluate the anti-bilharzial effects of the African Ocimum basilicum leaf extracts on infected snails and mice.

\section{MATERIALS AND METHODS}

\section{Ocimum basilicum Plant}

The fresh leaves of $O$. basilicum were collected from El- Orman Botanical Garden, Giza, Egypt, in June 2020. The plant was kindly identified by Mrs. Threase Labib, consultant of plant taxonomy at the Ministry of Agriculture; a voucher specimen (No. B6-2020) was kept at the Medicinal Chemistry Department, Theodor Bilharz Research Institute (Giza, Egypt).

\subsection{Preparation of the Ethanol Extract and Essential Oil \\ Ethanol extract.}

Dried powdered leaves of $O$. basilicum ( $200 \mathrm{~g}$ ) were placed in a glass percolator with ethanol $(1.2 \mathrm{~L})$ and allowed to stand at room temperature, then 
collected after $16 \mathrm{~h}$. The extraction process was repeated four times. Finally, the combined extract was filtered, concentrated under vacuum using rotavapor at $40^{\circ} \mathrm{C}$, and the weight of extract obtained was $16.46 \mathrm{~g}$ (Chatterjee $\boldsymbol{e t}$ al., 2011).

\section{Essential Oil.}

O. Ocimum basilicum fresh leaves $(2 \mathrm{~kg})$ were chopped into small pieces, and essential oil was extracted by hydro-distillation after $5 \mathrm{~h}$ using an apparatus of Clevenger type. Then oil was dried over anhydrous sodium sulfate $\left(\mathrm{Na}_{2} \mathrm{SO}_{4}\right)$, filtered, and stored in a sealed glass tube at $5^{\circ} \mathrm{C}$ for further analyses and biological activity tests (Saad et al., 2017).

\subsection{Phytochemical screening of the O. basilicum}

According to the conventional reported methods, identifying the major phytoconstituents of ethanolic extract was carried out (Gerhardt et al., 1983; Skaltsa et al., 1986; Baritaux et al., 1991; Grayer et al., 2001; Bais et al., 2002). The results were investigated by precipitation or change in color and exhibited glycosides, terpenoids, phenolics, and flavonoids. Qualitative and quantitative analysis of flavonoid and phenolic constituents of $O$. basilicum ethanolic extract carried out by HPLC method with UV- diode-array detector (Qureshi $\boldsymbol{e t}$ al., 2014). Analysis of the chemical compositions of the essential oil was performed by Gas Chromatography-Mass Spectrometry (GC/MS) following the procedures of (Adam, 1995).

\subsection{Antioxidant DPPH Assay}

Different concentrations of the extract were prepared in methanol and were added to $3 \mathrm{~mL}$ of $0.1 \mathrm{mM}$ methanolic solution of 1,1-diphenyl-2-picrylhydrazyl (DPPH). The tubes were shaken vigorously and allowed to stand for $30 \mathrm{~min}$ at room temperature in the dark. Changes in absorbance of samples were measured at $517 \mathrm{~nm}$. A control reading was obtained using methanol instead of the extract. Ascorbic acid, served as the standard free radical scavenging activity, was expressed as inhibition percentage and was calculated using the following formula:

$$
\% \text { inhibition }=\left(\left(\mathrm{A}_{0}-\mathrm{A}_{\mathrm{t}}\right) / \mathrm{A}_{0}\right) \times 100
$$

Where $A_{0}$ is the absorbance of the control, and $A_{t}$ is the absorbance of test samples. All the tests were performed in triplicates, and the results are reported as $\mathrm{IC}_{50}$, which is the amount of antioxidant necessary to decrease the initial DPPH concentration by 50\% (Mansoori et al., 2018).

\subsection{Cytotoxic activity SRB assay}

Evaluation of in vitro cytotoxic activity of Ocimum basilicum ethanol extract and essential oil against two human tumor cell lines, namely, hepatocellular carcinoma (HepG-2) and mammary gland breast cancer (MCF7), was tested by sulphorhodamine-B (SRB) assay at the National Cancer 
Institute in Egypt, according to the method of Skehan et al. (1990). The percentage of cell survival was calculated according to the following equation:

$\%$ Survival fraction $=($ OD of treated cell/O.D. of control cells $) \times 100$

According to the National Cancer Institute guideline, the extract with $\mathrm{IC}_{50}$ values less than $20 \mu \mathrm{g} / \mathrm{mL}$ is considered active (Houghton et al., 2007; Refahy et al., 2015).

\section{Experimental Design}

\subsection{Malacology Assays}

B. alexandrina snails were infected with $S$. mansoni miracidia (8 miracidia/snail) and divided into three groups, each containing ten snails. A group of infected mice was treated with $O$. basilicum ethanol extract $(50 \mathrm{ppm})$, another group was exposed to $O$. basilicum oil extract ( $50 \mathrm{ppm} / \mathrm{snail})$, and a third one served as untreated infected controls. Three replicates were prepared for each group. The experimental snails were transferred to clean dechlorinated water $\left(25 \pm 1^{\circ} \mathrm{C}\right)$ and fed daily with oven-dried lettuce leaves throughout the pre-patent and patent periods. Dead snails were removed daily, and the surviving snails have been examined weekly for cercarial shedding 24 days post-miracidia exposure. The number of snails that prevailed at the first shedding and the number of infected snails were calculated (Chernin and Dunavan 1962).

\subsection{Animals, infection, and regimens}

Six to seven-week-old male, Swiss albino mice $(20 \pm 2 \mathrm{~g})$ and $S$. mansoni cercariae were purchased from Schistosomiasis Biological Supply Center (SBSC) at Theodor Bilharz Research Institute (TBRI) in Giza, Egypt. Eight-week after subcutaneous infection (Muchirah et al., 2012) with a 100 cercariae/mouse, the animals were divided randomly into three groups $(n=5)$. One group received a 200 $\mathrm{mg} / \mathrm{kg}$ Ocimum basilicum ethanol extract, and another group received $100 \mu \mathrm{L} / \mathrm{kg}$ essential oil for five consecutive days each. A third group served as untreated infected control mice. In parallel, the fourth group with normal mice was maintained under the same laboratory and nutrition conditions. Two weeks post-treatment (10 weeks postinfection), mice were euthanized by decapitation and perfused with saline solution followed by formalin solution (10 minutes, each). Livers and small intestines were collected and processed for the parasitological and histopathological studies. The experiment was repeated three times.

\subsection{Parasitological Assays \\ Egg developmental stages (Oogram)}

The percentages of immature, mature, and dead eggs from the small intestinal wall of infected mice were computed from a hundred eggs per intestinal segment. Immature eggs were characterized by partially developed embryos with clear 
transparent parts within the eggs shell. The mature ones contain fully developed miracidium. Dead eggs exhibited dark retraction and irregular outlines of dead seeds. Three segments per animal were examined (Pellegrino and Jane Faria 1965).

\section{Tissue eggs load and worm burden}

The number of eggs per gram tissue (liver and intestine) of infected mice was determined. The mean number of worms/mouse was determined for each experimental group (Ebeid et al., 2005).

\subsection{Histopathological Parameters}

Livers were harvested from the mice, fixed in $10 \%$ buffered formalin, and processed to paraffin blocks. Sections ( $4 \mu \mathrm{m}$ thick) were cut every $250 \mu \mathrm{m}$ to avoid measuring the same granuloma. Five liver sections were prepared from each animal and stained with hematoxylin and eosin and Masson trichrome stains. An ocular micrometer was utilized to measure the non-contiguous granulomas; each contained a single intact or degenerated egg. The mean diameter of each granuloma was calculated by measuring 2 diameters of the lesion at right angles to each other (Ebeid et al., 2005). Granuloma structural configurations, including cellular components and associated hepatic histopathological changes, were recorded.

\section{Statistical analysis}

Data were expressed as means \pm SD or percentage and analyzed using the statistical package SPSS (version 7.5 Windows). Comparisons between the groups were made using Chi-square test for the qualitative variables and the $t$-student test for the quantitative variables. The probability value less than 0.05 was considered statistically significant.

\section{RESULTS}

HPLC fingerprint chromatography was applied to compare the retention time of the extract constituents and standard solutions. The chromatography detected fourteen significant peaks to which the retention time of the standards matched. The identified components are listed in the Table (1), showing that caffeic acid accounted for the highest content, whereas carnosic acid accounted for the most negligible content. On the other hand, the analysis of the essential oil obtained by GC/MS demonstrated twenty-five compounds. The greatest concentration was due to the linalool $(21.52 \%)$, and the least in concentration was due to phytol acetate $(0.08 \%)$ depicted in Figure (1) and Table (2). The DPPH assay recorded the radical solid scavenging effect of the ethanol extract at $27.13 \mu \mathrm{g} / \mathrm{mL} ; \mathrm{SC}_{50}$ value.

\section{The effect of the plant extracts on snails}

The exposure of the snails to a mono-treatment of $O$. basilicum ethanol extract and essential oil resulted in a highly significant $(p<0.0001)$ increase (95 and 
$96 \%$, respectively) of the survival rates and a significant $(p<0.001)$ decrease $(35 \%$ and $21 \%$, respectively) of the infection rates compared to the normal controls $(85 \%$ and $95 \%$, respectively) as shown in Table (3).

\section{The effect $O$. Basilicum extracts on the stages of the Schistosoma parasite}

The mice treated with either ethanol extract or oil showed a significant reduction $(p<0.0001)$ of the intestinal and hepatic egg loads and worm counts compared to the controls (22061.33 \pm 451.95 and 21458.3 \pm 1011.99 ; respectively). However, the hepatic egg counts in of mice treated with the $200 \mathrm{mg} / \mathrm{kg}$ ethanol extract $(12558.25 \pm 1033.37)$ were significantly $(p<0.01)$ more than their counterparts $(13870.00 \pm 730.36)$ of mice treated with $100 \mu \mathrm{l} / \mathrm{kg}$ essential oil as depicted in the table (4).

\section{The histopathological changes of the definitive host}

Compared to the control, a significant $(p<0.0001)$ diminution in the hepatic granuloma size (35.37\%), numbers (16.2 \pm 1.21 vs. 10.47 \pm 1.45$)$, and cellular type (78 vs. 62) was due to the treatment with $100 \mu \mathrm{L} / \mathrm{kg}$ essential oil. Yet, the percentages of hepatic cellular granulomas $(62 \%)$ and degenerated eggs $(15 \%)$ were significantly greater ( $p<0.0001$ and $p<0.001$, respectively) in the mice treated with a $100 \mu \mathrm{L} / \mathrm{kg}$ essential oil than their counterparts of the mice treated with $200 \mathrm{mg} / \mathrm{kg}$ ethanol extract (55\% and 12\%, respectively) as shown in Table (5). The liver tissue sections of untreated-infected mice showed various lobular, portal, cellular, and fibro-cellular granulomas with intact eggs. The lobular granulomas were infiltrated with Kupffer cells, monocytes, and mild fibrosis. Meanwhile, the portal granulomas had an influx of inflammatory cells with fibrous tissue disposition. The highest percentage of fibro cellular granulomas was detected in the liver tissues of the mice treated with 200 $\mathrm{mg} / \mathrm{kg}$ ethanol extract. However, the hepatocytes were ameliorated in the groups treated with both extracts (Figure 2).

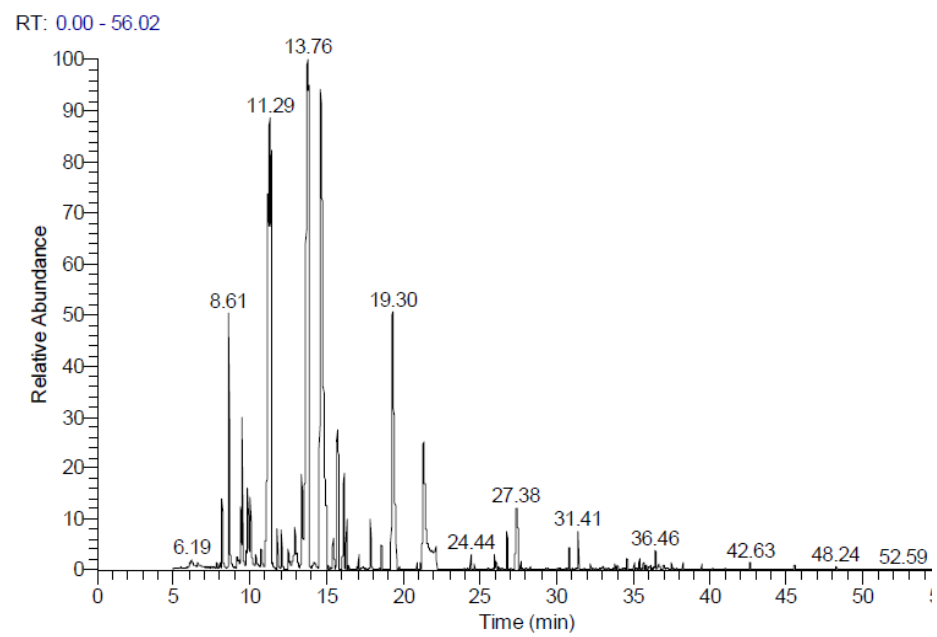

Figure 1: The chemical constituents of $O$. basilicum essential oil using HPLC techniques 
Table (1): The constituents of $O$. basilicum ethanolic extracts by reverse phase HPLC with diode-array detection

\begin{tabular}{|c|c|l|c|}
\hline No. & \multicolumn{1}{|c|}{$\begin{array}{c}\text { Retention time } \\
\text { (min) }\end{array}$} & \multicolumn{1}{|c|}{$\begin{array}{c}\text { Components } \\
\text { mg/100 } \mathbf{~ m L} \\
\text { extract) }\end{array}$} \\
\hline 1 & 6.11 & Catechin & 451.71 \\
\hline 2 & 11.4 & Rutin & 179.14 \\
\hline 3 & 17.44 & Caffeic acid & 553.46 \\
\hline 4 & 25.99 & Dihydrokaempferol-3-O-glucoside & 91.87 \\
\hline 5 & 27.15 & Luteolin acetyl-glucuronide & 86.02 \\
\hline 6 & 29.27 & Luteolin 5-O-glucoside & 222.01 \\
\hline 7 & 30.04 & Ferulic acid, & 182.25 \\
\hline 8 & 34.56 & Rosmarinic acid & 506.70 \\
\hline 9 & 35.14 & Caffeoyl -3-O-rutiniside & 146.18 \\
\hline 10 & 38.49 & Apigenin, & 99.76 \\
\hline 11 & 45.32 & Carnosic acid & 79.14 \\
\hline 12 & 50.16 & Chlorogenic acid & 237.01 \\
\hline 13 & 51.41 & Acacetin & 312.05 \\
\hline 14 & 53.20 & Ursolic acid & 97.18 \\
\hline
\end{tabular}

Table (2): The chemical constituents identified from $O$. basilicum essential oil by GC-MS analysis.

\begin{tabular}{|c|c|l|c|c|}
\hline No. & $\begin{array}{c}\text { Retention } \\
\text { time (min) }\end{array}$ & \multicolumn{1}{|c|}{ components } & $\begin{array}{c}\text { Polecular } \\
\text { Weight }\end{array}$ \\
\hline 1 & 8.18 & $\alpha$-Pinene & 0.80 & 136 \\
\hline 2 & 8.61 & Camphene & 3.06 & 136 \\
\hline 3 & 9.17 & Benzaldehyde & 0.21 & 106 \\
\hline 4 & 9.47 & $\beta$-Pinene & 1.78 & 136 \\
\hline 5 & 10.02 & $\alpha$ - Myrcene & 0.74 & 136 \\
\hline 6 & 10.37 & 1-Phellandrene & 0.20 & 136 \\
\hline 7 & 11.29 & 1,8 - Cineole & 16.68 & 154 \\
\hline 8 & 11.77 & Carvone & 5.51 & 150 \\
\hline 9 & 12.02 & $\gamma$ - Terpinene & 0.43 & 136 \\
\hline 10 & 12.48 & Linalool oxide & 0.41 & 170 \\
\hline 11 & 13.76 & Linalool & 21.52 & 154 \\
\hline 12 & 14.17 & P-mentha-1(7),8-dien-2-ol & 0.13 & 152 \\
\hline 13 & 14.60 & Camphor & 17.02 & 152 \\
\hline 14 & 15.71 & p-Cymene & 5.35 & 134 \\
\hline 15 & 16.14 & Geraniol formate & 2.14 & 182 \\
\hline 16 & 16.31 & Myrtenol & 0.53 & 152 \\
\hline 17 & 17.10 & Nerol & 0.14 & 154 \\
\hline 18 & 17.86 & Isopulegol & 0.72 & 154 \\
\hline 19 & 18.58 & Bornyl acetate & 0.26 & 196 \\
\hline 20 & 19.28 & Germacrene & 7.37 & 204 \\
\hline 21 & 24.43 & Methyl-3-phenyl-2-propenoate & 0.19 & 162 \\
\hline 22 & 26.76 & Cubenol & 0.48 & 222 \\
\hline 23 & 27.38 & $\alpha-$ Cadinol & 2.09 & 222 \\
\hline 24 & 34.61 & Delta-3-Carene & 0.11 & 136 \\
\hline 25 & 38.26 & Phytol acetate & 0.08 & 338 \\
\hline & & & & \\
\hline
\end{tabular}


Table 3: Effect of the 4-week exposure of $50 \mathrm{ppm} O$. basilicum extracts on $B$. alexandrina snails' infection and survival rates

\begin{tabular}{|l|c|c|}
\hline Infected snails & \% Infection rate & \% Survival rate \\
\hline Untreated Control & $95 \%$ & $80 \%$ \\
\hline Treated with ethanol extract & $35 \%^{* * *}$ & $95^{* * *}$ \\
\hline Treated with essential oil & $21 \%^{* * *}$ & $96^{* * *}$ \\
\hline
\end{tabular}

*** $(P<0.001)$ highly significant

Table 4: Effect of the $O$. basilicum extracts on $S$. mansoni worm burden, ova development, and egg count in the intestines and livers of the experimental mice, 10 weeks post-infection.

\begin{tabular}{|c|c|c|c|c|c|c|c|c|c|}
\hline \multirow{2}{*}{ Groups } & \multicolumn{2}{|c|}{ Ova count/g tissue } & \multicolumn{3}{|c|}{$\%$ Ova developmental stages } & \multicolumn{4}{|c|}{$\begin{array}{c}\text { Mean worm burden } \pm \text { SD } \\
\text { in Liver and Porto-mesenteric }\end{array}$} \\
\hline & Intestine & Liver & Dead & Mature & Immature & Couples & Female & Male & Total \\
\hline $\begin{array}{l}\text { Infected } \\
\text { Control }\end{array}$ & $\begin{array}{l}22061.33 \\
\pm 451.95\end{array}$ & $\begin{array}{c}21458.3 \pm \\
1011.99\end{array}$ & $\begin{array}{r}05.67 \\
\pm 1.53\end{array}$ & $\begin{array}{l}46.67 \pm \\
2.08\end{array}$ & $47.67 \pm 0.58$ & $\begin{array}{l}12.33 \pm \\
1.53\end{array}$ & $\begin{array}{l}0.67 \pm \\
1.15\end{array}$ & $\begin{array}{c}2.67 \pm \\
\underline{0} .58\end{array}$ & $28.00 \pm \underline{2} .65$ \\
\hline $\begin{array}{c}200 \mathrm{mg} / \mathrm{kg} \\
\text { ethanol extract }\end{array}$ & $\begin{array}{c}14280.00 \\
\pm \\
1546.91^{* *}\end{array}$ & $\begin{array}{c}12558.25 \\
\pm \\
1033.37^{* * *}\end{array}$ & $\begin{array}{c}14.75 \\
\pm^{* * *} \\
3.21^{* * *}\end{array}$ & $\begin{array}{c}45.5 \pm \\
7.41\end{array}$ & $39.75 \pm 7.41$ & $\begin{array}{l}7.50 \pm \\
1.29^{* * * *}\end{array}$ & $\begin{array}{c}0.75 \pm \\
0.96\end{array}$ & $2.0 \pm 0.82$ & $\begin{array}{l}17.75 \pm \\
1.89^{* * * *}\end{array}$ \\
\hline $\begin{array}{c}100 \mu \mathrm{L} / \mathrm{kg} \\
\text { essential oil }\end{array}$ & $\begin{array}{c}12853.33 \\
\pm \\
772.05^{* * *}\end{array}$ & $\begin{array}{c}13870 \pm \\
730.36^{\text {**** }}\end{array}$ & $\begin{array}{c}17.00 \\
\pm \\
4.36^{* * *}\end{array}$ & $\begin{array}{c}46.67 \pm \\
7.23\end{array}$ & $\begin{array}{l}35.33 \pm \\
4.73^{* * * *}\end{array}$ & $\begin{array}{l}7.00 \pm \\
1.00^{* * * *}\end{array}$ & 0.00 & $\begin{array}{c}1.67 \pm \\
0.58\end{array}$ & $\begin{array}{l}15.67 \pm \\
1.53^{* * *}\end{array}$ \\
\hline
\end{tabular}




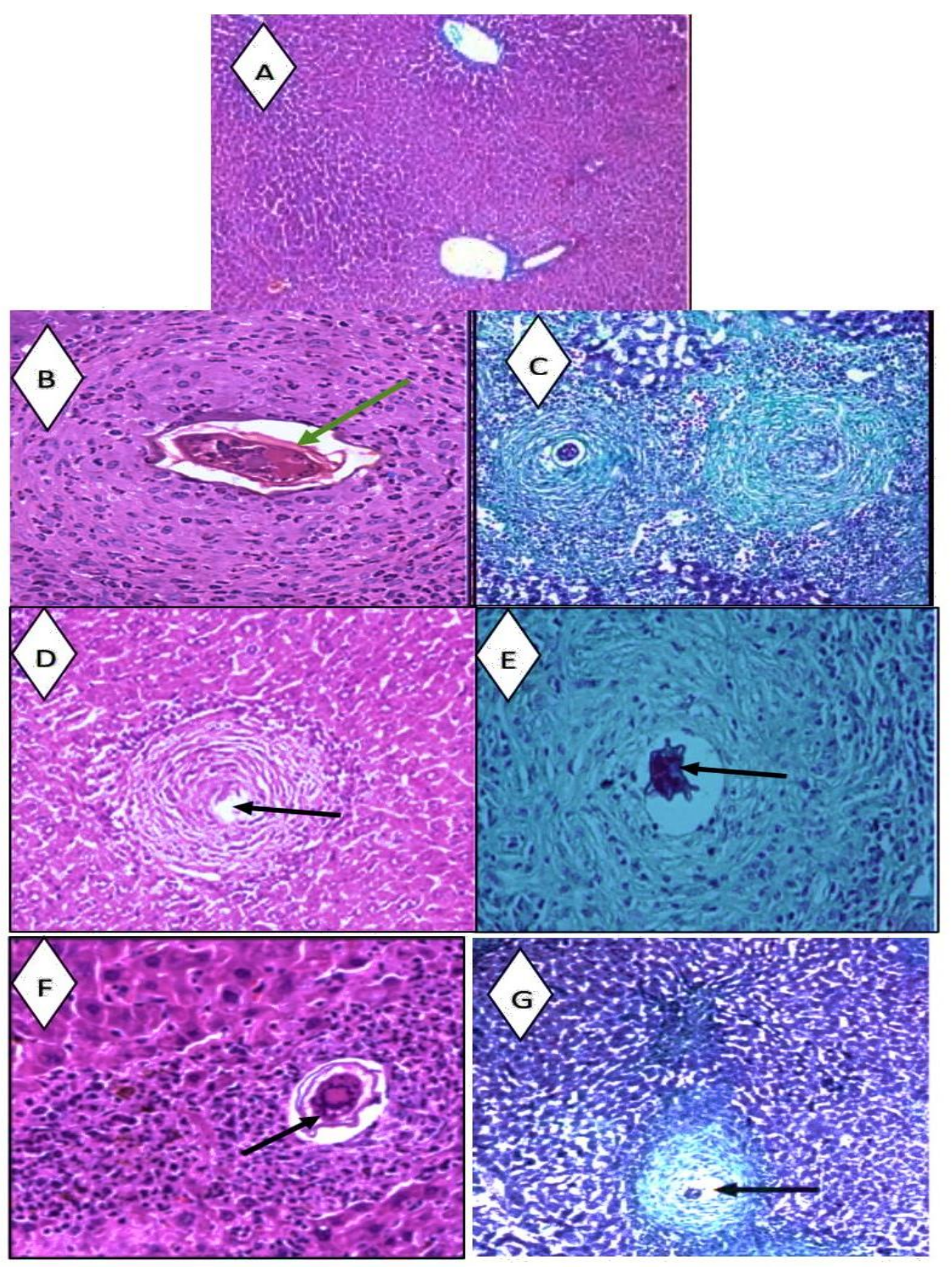

Figure 2: (A) Healthy hepatic tissue with intact hepatocytes in normal mice, $\mathrm{H}$ and $\mathrm{E}$, $\mathrm{x} 10$.

(B and C) Hydropic hepatocytes, an influx of monocytes, eosinophils, and fibrocytes surrounding intact Schistosoma eggs (green arrow) in the infected mice (H and E, x20; MT, $\mathrm{x} 10$, respectively). (D and E) Ameliorated hepatocytes and well-defined granuloma with a mild number of monocytes and an increase of fibrocytes surrounding degenerated eggs (black arrow) in the liver sections of mice treated with $200 \mathrm{mg} / \mathrm{kg}$ ethanol extract. $\mathrm{H}$ and $\mathrm{E}$, x20; 
MT, $x 40$, respectively. ( $F$ and $E$ ) intact hepatic architectures with a considerable number of lymphocytes, eosinophils ( $\mathrm{H}$ and $\mathrm{E}, \mathrm{x} 20)$, and fibrocytes (MT x10) in mice treated with $100 \mu 1 / \mathrm{kg}$ essential oil, respectively.

\section{DISCUSSION}

Schistosomiasis is reported as the most second prevalent disease in the world after malaria (WHO 2021). The transmission of Schistosoma spp. is controlled by molluscicides, and the treatment is managed by the commercial drug praziquantel. Recently, several cases of resistance to the therapeutic agents (Ismail et al. 1999, Gryseels et al. 2002, Doenhoff et al. 2008, Melman et al. 2009, Zhang and Coultas, 2013, Mossalem et al. 2014) and molluscicides were reported (Duarte Galhardo de Albuquerque et al., 2020).

Over the past years $(\mathbf{2 0 1 3}, \mathbf{2 0 1 4}, \mathbf{2 0 1 7})$, Mossalem and colleagues worked on the folkloric herbal extracts to control schistosomiasis transmission via disturbing their specific snails, the intermediate host. In this study, the demonstrated antioxidant constituents of $O$. basilicum ethanol extract and essential oil are verified by matching them with many references (Gerhardt et al. 1983, Skaltsa et al., 1986, Baritaux et al., 1991, Grayer et al., 2001, Bais et al., 2002). We used the lowest dose of either plant extract, which is 50ppm, because all the tested concentrations had harmless impacts on the infected snails for the fact of being antioxidants, not molluscicides. It was believed that a pesticide manipulated Biomphalaria alexandrina snails ameliorated when treated with $O$. Ocimum oil extract (Mossalem and Ibrahim, 2019). Hence, we designed this research work to assess and compare the impacts of Ocimum basilicum ethanol and oil extracts on both Schistosoma mansoni intermediate and definitive hosts.

Our data showed that the treatment protocols significantly increased the survival rates and decreased the infection rates of $S$. mansoni-infected $B$. alexandrina snails, which agrees with other findings (Sestili et al. 2018, Mossalem and Ibrahim, 2019). $O$. basilicum extracts may have their protective influences through the active antioxidant components such as polyphenolic and flavonoids (Mossalem and Ibrahim, 2019).

The mice infected and treated with $O$. basilicum essential oil had the female worm count vanished (zero) alongside a significant reduction of ova disposition in intestinal tissues. These results may indicate a metabolic action mode on the development or fecundity of female worms, which is supported by observations reported from an in vitro study used $O$. basilicum ethanol and hexane extracts on earthworms (Clement Osei Akoto et al., 2020). Therefore, we suggest further morphological studies and protein analysis on the Schistosome adult worms to validate this hypothesis.

The higher number of fibro cellular hepatic granulomas in the group treated with ethanol extract $(200 \mathrm{mg} / \mathrm{kg})$ may indicate an acceleration towards the chronic 
inflammation in favor of Th2 response. Unlikely, the major cellular granulomas in the hepatic tissues of mice treated with the oil extract retained the Th1 response of the acute phase. These data may explain the high degeneration rate of eggs in the hepatic granulomas of the mice treated with $100 \mu 1 / \mathrm{kg}$ oil extract (Xu et al. 2010).

In conclusion, the biochemical assays, malacology assessments, and in vivo model indicated a potential therapeutic effect of $O$. basilicum ethanol and oil extracts. Further studies are needed to consider combining $O$. basilicum extracts with the other medicinal herbs tested for their actions on schistosomiasis mansoni to develop an efficient treatment and reduce or eradicate the transmission.

\section{Acknowledgments}

Funds supported this research work from Research Projects Committee, Theodor Bilharz Research Institute, Giza, Egypt (No. 100M).

\section{CONCLUSION}

$O$. basilicum was considered a prolific source for several biologically active metabolites. The plant's ethanol extract and essential oil showed appreciable antischistosomiasis activities in the intermediate and definitive hosts.

\section{REFERENCES}

Abdulla, M.H.; Lim, K. C.; Sajid, M.; McKerrow,J. H. and Caffrey, C.R. (2007). Schistosomiasis Mansoni: Novel Chemotherapy Using a Cysteine Protease Inhibitor. PLoS Medicine, 4(1), e14. doi:10.1371/journal.pmed. $\underline{0040014}$

Adams, R. P. (1995). Identification of Essential Oil Components by Gas Chromatography/Mass Spectrometry. Allured Publishing Corporation; Carol Stream, IL, USA: [Google Scholar] [Ref list]

Archibald, R.G. (1933). The use of the fruit of the tree balanites aegyptiaca in the control of Schistosomiasis in Sudan. Trans. R. Soc. Trop. Med. Hyg. 27:207210. DOI: 10.1016/S0035-9203(33)90011-5. [CrossRef] [Google Scholar] [Ref list]

Bais, H.P.; Walker, T.S.; Schweizer, H.P. and Vivanco, J.M. (2002). Root specific elicitation and antimicrobial activity of rosmarinic acid in hairy root cultures of Ocimum basilicum. Plant Physiol. Biochem. 40, 983-995. 
Baritaux, O.; Amiot, M.J.; Richard, H. and Nicolas, J. (1991). Enzymatic browning of basil (Ocimum basilicum L) studies on phenolic compounds and polyphenol oxidase. Sci. Aliments, 11, 49- 62.

Bergquist, R.; Utzinger, J. and Keiser, J. (2017). Controlling Schistosomiasis with praziquantel: How much longer without a viable alternative? Infect Dis Poverty 6, 74 https://doi.org/10.1186/s40249-017-0286-2

Chatterjee, M.; Verma, P., Maurya, R. and Palit, G. (2011). Evaluation of ethanol leaf extract of Ocimum sanctum in experimental models of anxiety and depression. Pharmaceutical Biology 49:5, 477-483, DOI: 10.3109/13880209.2010.523832

Chernin, E. and Dunavan, C.A. (1962). The influence of host-parasite dispersion upon the capacity of Schistosoma mansoni miracidia to infection Australorbis glabratus. Amer. J. Trop. Med. Hyg. 11:455-471.

Akoto, C.O.; Acheampong, A.; Boakye, Y.D.; Naazo, A.A. and Adomah, D.H. (2020). "Anti-Inflammatory, Antioxidant, and Anthelmintic Activities of Ocimum basilicum (Sweet Basil) Fruits." Journal of Chemistry, ID 2153534, 9 pages. https://doi.org/10.1155/2020/2153534

Cort, W.W.; Ameel, D.J. and Van der Woude, A. (1954). Germinal development in the sporocysts and rediae of the digenetic trematodes. Exp. Parasitol. 3, 185-225. [PubMed] [Google Scholar] [Ref list]

Doenhoff, M.J.; Cioli, D. and Utzinger, J. (2008). Review Praziquantel: mechanisms of action, resistance and new derivatives for Schistosomiasis. Curr Opin Infect Dis.; 21(6):659-67. [PubMed] [Ref list]

Duarte Galhardo de Albuquerque, R.D.; Mahomoodally, M.F.; Lobine, D.; Suroowan, S. and Rengasamy, K.R. (2020). Botanical Products in the Treatment and Control of Schistosomiasis: Recent Studies and Distribution of Active Plant Resources According to Affected Regions. Biology (Basel). 2020;9(8):223. Doi:10.3390/biology9080223

Ebeid, F.; Mahmoud, S.S.; Botros, S.S. and Badawy, A.A. (2005). Evaluation of the antibilharzial activity of mirazid versus praziquantel against $S$. haematobium: an experimental study. Egypt J Schistosomiasis Infect Endm Dis. 2005; 27: 25-37. 
Fahmy, A.; Abuelenain ,G.L.; Rasheed, N. and Abdou, A. (2021). 'de Novo' repurposing of Daflon as an anti-intestinal parasitic drug in experimental giardiasis. Exp. Para, online 15 June 2021. https://doi.org/10.1016/j.exppara.2021.108124

Gryseels, B.; Mbaye, A.; DeVlas, S.J.; Stelma, F.F.; Guissé, F. and Lieshout, L.V. et al. (2002). Are poor responses to praziquantel for the treatment of Schistosoma mansoni infections in Senegal due to resistance? An overview of the evidence. Trop. Med. Int. Health (6): 864-873.

Doi:10.1046/j.1365- 3156.2001.00811.x

Gerhardt, U. and Schroter. (1983). A Rosmarinic acid-an antioxidant occurring naturally in herbs. Fleischwirtschaft, 63, 1628-1630.

Gouveia, M.J.; Brindley, P.J; Gärtner, F.; Costa, J. and Vale, N. (2018). Drug Repurposing for Schistosomiasis: Combinations of Drugs or Biomolecules. Pharmaceuticals (Basel, $\quad$ Switzerland), 11(1), 15. https://doi.org/10.3390/ph11010015

Grayer, R.J.; Veitch, N.C.; Kite, G.C.; Price, A.M. and Kokubun, T. (2001). Distribution of 8-oxygenated leaf-surface flavones in the genus Ocimum. Phytochemistry, 56, 559-567.

Hostettmann, K. (1984). On the use of plants and plant-derived compounds for the control of Schistosomiasis. Naturwissenschaften; 71(5):247-51.[PubMed] [Ref list]

Ismail, M.; Botros, S.; Metwally, A.; William, S., Farghally, A.;Tao, L.F.; Day, T.A. and Bennett, J.L. (1999). Resistance to praziquantel: direct evidence from Schistosoma mansoni isolated from Egyptian villagers. Am J Trop Med Hyg. 60(6):932-5. [PubMed] [Google Scholar] [Ref list]

Jiwajinda, S.; Santisopasri, V.; Murakami, A.; Sugiyama, H.; Gasquet, M.; Riad, E.; Balansard, G. and Ohigashi, H. (2002). In vitro anti-tumor promoting and antiparasitic activities of the quassinoids from Eurycoma longifolia, a medicinal plant in Southeast Asia. J Ethnopharmacol. 82(1):55-8. [PubMed] [Ref list]

King, C.H.; Muchiri, E.M. and Ouma, J.H. (2000). Evidence Against Rapid Emergence of Praziquantel Resistance in Schistosoma haematobium, 
Kenya. Emerging Infectious Diseases; 6(6):585-594.

Doi:10.3201/eid0606.000606.

Lemma, A.; Goll, P.; Duncan, J.and Ma-zengia, B. (1978). Control of Schistosomiasis by the Use of Endod in Adwa, Ethiopia: Result of A 5-Year Study. Ministry of Health Cairo Proceedings of International Conference on Schistosomiasis; Cairo, Egypt: Ministry of Health Cairo; Cairo, Egypt; pp. 415436. [Google Scholar] [Ref list]

Li P, Nanes Sarfati, D. and Xue, Y. et al. (2021). Single-cell analysis of Schistosoma mansoni identifies a conserved genetic program controlling germline stem cell fate. Nat Commun 12, 485 https://doi.org/10.1038/s41467-020-20794-w

Mansoori, M.H.; Gupta, M.K.; Mishra, V.; Nishika, Y. and Manish, V. (2018). Evaluation of the antioxidant activity of fruit extracts of indigenous medicinal plant, Zizyphus xylopyrus (Retz.) Wild. Int. J. Green Pharm. 12 (4) | S863. DOI: $10.22377 /$ ijgp.v12i04.2267.

McManus, D.P.; Dunne, D.W. and Sacko, M .et al. (2018). Schistosomiasis. Nat Rev Dis Primers 4, 13. https://doi.org/10.1038/s41572-018-0013-8

Melman,, S.D.; Steinauer, M.L.; Cunningham, C.; Kubatko, L.S.; Mwangi, I.N.;Wynn, N.B.; Mutuku, M.W.; Karanja, D.M.; Colley, D.G.; Black, C.L.; Secor, W.E.; Mkoji, G.M .and Loker, E.S. (2009). Reduced susceptibility to praziquantel among naturally occurring Kenyan isolates of Schistosoma mansoni. PLoS Negl Trop Dis., 3(8): e504.

Mølgaard, P.; Nielsen, S.B.; Rasmussen, D.E.; Drummond, R.B.; Makaza, N. and Andreassen, J. (2001). Anthelmintic screening of Zimbabwean plants traditionally used against Schistosomiasis.

J Ethnopharmacol; 74(3):257-64. [PubMed] [Ref list]

Mossalem, H.S and Ibrahim, M.A. (2019). The ameliorative potential of the ethanol extract of the plant Ocimum basilicum on Biomphalaria alexandrina snails exposed to the insecticide Bestacid. Egyptian Journal of Aquatic Biology and Fisheries, Zoology Department, Faculty of Science, Ain Shams University, Cairo, Egypt. Vol. 23 (1):161-172 DOI: 10.21608/EJABF.2019.26691

Mossalem, H.S.; Ghareeb,, M..A.; Refahy, L.A.; Mohamed, A.S. and Habib, M.R. (2017). Gas chromatography-mass spectrometry analysis and antioxidant activity 
of Punica granatum L. Peels and its role as immunostimulant against Schistosoma mansoni infection in Biomphalaria alexandrina. Asian $\mathrm{J}$.

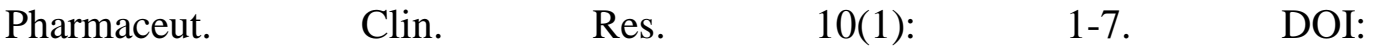
http://dx.doi.org/10.22159/ajpcr.2016.v9i2.15107

Mossalem, H.S.; Abdel-Hamid, H. and El-Shinnawy, N.A. (2013). Impact of artemether on some histological and histochemical parameters in Biomphalaria alexandrina, African Journal of Pharmacy and Pharmacology; 7: 2220-2230. DOI 10.5897/AJPP2013.3762

Mossalem, H.S. and Mossa, A.H. (2014). Effect of rice bran extract on immunological and physiological parameters of Biomphalaria alexandrina snails infected with Schistosoma mansoni. African Journal of Pharmacy and Pharmacology; 8(22), 621-628.

DOI 10.5897/AJPP2013.3965

Mozley, A. Xxvi (1939). The freshwater mollusca of the Tanganyika territory and Zanzibar protectorate, and their relation to human Schistosomiasis. Trans. R. Soc. Edinb; 59:687-744. DOI: 10.1017/S0080456800017403. [CrossRef] [Google Scholar] [Ref list]

Muchirah, P.N.; Yole, D.S.; Kutima, H.; Waihenya, R.; Kuria, K.M. and Mokua, J. (2012). Determination of effective praziquantel dose in different mouse strains: $\mathrm{BALB} / \mathrm{c}$ and Swiss mice in treatment of Schistosoma mansoni. Journal of Clinical Immunology and Immunopathology Research; 4(2):12-21.

Olivier, L. and Mao, C.P. (1949). The early larval stages of Schistosoma mansoni Sambon, 1907 in the snail host, Australorbis glabratus (Say, 1818). J. Parasitol. 35, 267-275. [PubMed] [Google Scholar] [Ref list]

Pearce, E.J. and MacDonald, A.S. (2002). The immunobiology of Schistosomiasis. Nat. Rev. Immunol. 2, 499-511. [PubMed] [Google Scholar] [Ref list]

Pellegrino, J. and Jane Faria. (1965). The Oogram Method for the Screening of Drugs in Schistosomiasis mansoni. Am J Trop Med Hyg; 14(3):363-369. https://doi.org/10.4269/ajtmh.1965.14.363 
Qureshi, M.N.; Stecher, G. and Bonn, G.K. (2014). Determination of total polyphenolic compounds and flavonoids in Juglans regia leaves. Pak J Pharm Sci. 27(4):865-9. PMID: 25015453.

Saad, A.M.; Mohammed, M.M.D.; Ghareeb, M.A.,; Ahmed, W.S. and Farid, M.A. (2017). Chemical Composition and Antimicrobial Activity of the Essential Oil of the Leaves of Cupressus macrocarpa Hartweg. ex Gordon. J App Pharm Sci. 7 (09): 207-212.

Simoben, C.V.; Ntie-Kang, F.; Akone, S.H. and Sippl, W. (2018). Review Compounds from African Medicinal Plants with Activities Against Selected Parasitic Diseases: Schistosomiasis, Trypanosomiasis, and Leishmaniasis. Nat Prod Bioprospect. 8(3):151-169. [PubMed] [Ref list]

Skaltsa, H. and Philianos, S. (1986). Contribution a' l'e'tude chimique d'Ocimum basilicumL. Plantes Me’d. Phytothe'r. 20, 291- 299.

Skehan, P.; Storeng, R.; Scudiero, D.; Monks, A. and McMahon, J. et al. (1990). New colorimetric cytotoxicity assay for anticancer-drug screening. J Natl Cancer Inst. 82: 1107-1112.

Sokal, R.R and Rohif, F.J. (1981). Biometry. 2nd ed. San Francesco: WH Freeman and Company; 1981, p. 35.

Utzinger, J.; Chollet, J.; You, J.; Mei, J.; Tanner, M. and Xiao, S. (2001). Effect of combined treatment with praziquantel and artemether on Schistosoma japonicum and Schistosoma mansoni in experimentally infected animals. Acta Trop. 80(1):9-18. [PubMed] [Google Scholar] [Ref list]

Whitfield, P.J and Evans, N.A. (1983). Parthenogenesis and asexual multiplication among parasitic platyhelminths. Parasitology 86, 121-160 [PubMed] [Google Scholar] [Ref list]

Waiganjo, N.; Yole, D.S. and Ochanda, H. (2014). The anti-schistosomal activity of five plant extracts on Swiss white mice infected with Schistosoma mansoni. IOSR J. Pharm. Biol. Sci. 9:49-53. DOI: 10.9790/300809164953. [CrossRef] [Google Scholar] [Ref list]

Wager, V.A. (1936). The possibility of eradicating bilharzia by extensive planting of the tree balanltes. South. Afr. Med. J. 10:10-11. [Google Scholar] [Ref list] 
Xu, X.; Wen, X.; Chi, Y.; He L; Zhou, S.; Wang, S.; Zhao, J.; Liu, F. and Su, C. (2010). "Activation-Induced T Helper Cell Death Contributes to Th1/Th2 Polarization following Murine Schistosoma japonicum Infection", BioMed Research International. Article ID 202397, 12 pages https://doi.org/10.1155/2010/202397

Yousif, F.; Wassel, G.; Boulos, L.; Labib, T.; Mahmoud, K.; El-Hallouty, S.; El Bardicy, S.; Mahmoud, S.; Ramzy, F.; Gohar, L.; El-Manawaty, M.; El Gendy, M.A.; Fayad, W. and El-Menshawi, B. (2012). Contribution to in vitro screening of Egyptian plants for schistosomicidal activity. Pharm Biol. 50(6):732-9. [PubMed] [Ref list]

Zhang, S. and Coultas, K.A. (2013). Identification of Plumbagin and Sanguinarine as effective chemotherapeutic agents for the treatment of Schistosomiasis. Int. J. Parasitol., 3: 28-34. 


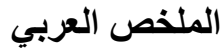 \\ حنان مسلم، جيهان لبيب، اسماء محمد، تامر محمد، خالد زايد وسهير محمود معهد تيودوربلهارس للبحوث، مصر.}

يعد داء البلهارسيا أحد أكثر الأمر اض انتشارًا في جميع أنحاء العالم على الرغم من عقار البرازيكوانتيل التقليدي ومبيدات الرخويات. تم تكثيف البحث عن علاج سريري خالٍ من الاعر اض الجانبية ومبيدات للرخويات صديقة

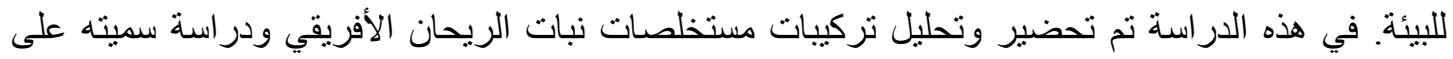

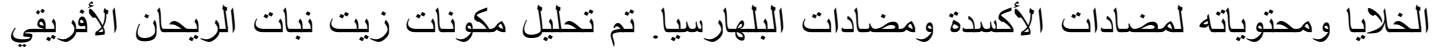

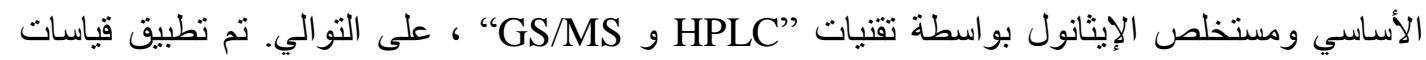

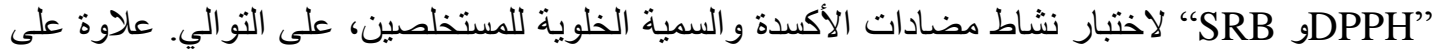

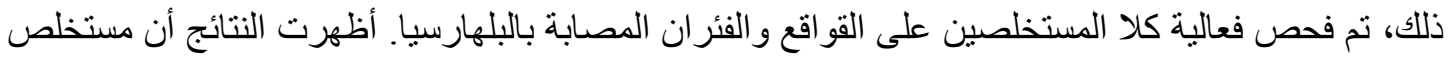

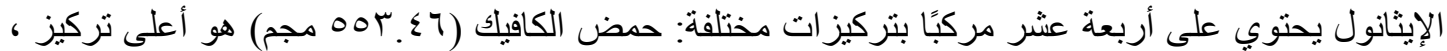

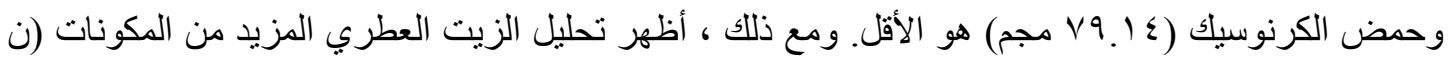

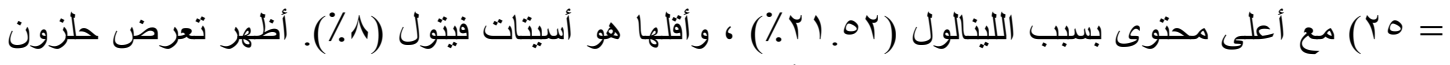
"B. alexandrina"

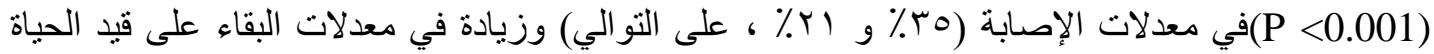

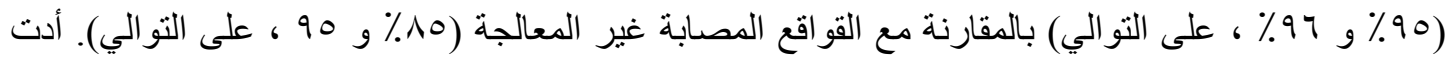

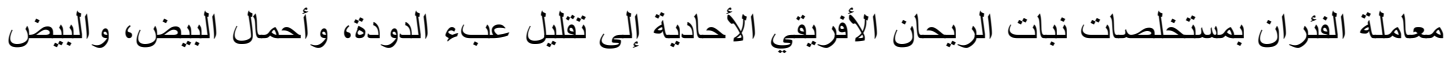

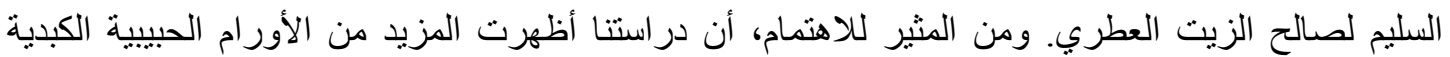

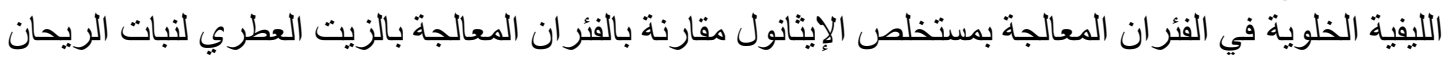

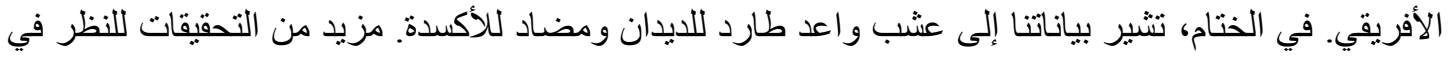

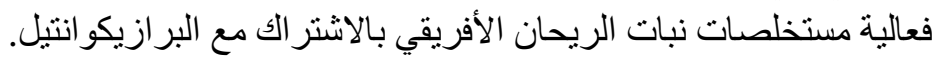

